\title{
AGRONOMY
}

DOI https://doi.org/10.30525/978-9934-26-111-4-45

\section{ТЕНДЕНЦІї ВИРОЩУВАННЯ СОЇ В КИЇВСЬКІЙ ОБЛАСТІ В УМОВАХ ЗМІН КЛІМАТУ}

\section{Голодна А. В.}

доктор сільськогосподарських наук, старший науковий співробітник, головний науковий співробітник відділу технологій зернобобових, круп'яних і олійних культур

Національний науковий цеентр «Інститут землеробства Національної академії аграрних наук України»

\section{Губенко Л. В.}

кандидат сільськогосподарських наук, старший науковий співробітник, провідний науковий співробітник відділу технологій зернобобових, круп'яних і олійних культур

Національний науковий цеентр «Інститут землеробства Національної академії аграрних наук Украӥни»

\section{Любчич О. Г.}

кандидат сільськогосподарських наук, завідувач відділу технологій зернобобових, круп'яних і олійних культур Національний науковий центр «Інститут землеробства Національної академії аграрних наук України» смт Чабани, Києво-Святочинський район, Київська область, Україна

Клімат України формується під впливом глобального клімату i на сьогодні характеризується тенденцією до потепління, що супроводжується зміною температурного режиму, зволоження та збільшенням частоти кліматичних аномалій [1].

В останні п’ятнадцять років посівні площі сої в Україні значно зросли, особливо в зоні Лісостепу та Полісся [2-4], й за площами посіву, урожайністю та валовими зборами культура є лідером серед олійних і зернобобових культур [5].

У Київській області, що відноситься до зони діяльності ННЦ «Інститут землеробства НААН», останнє десятиліття посівні площі 
культури займають до 10 \% від загальної площі в країні. 32006 р. площі під соєю в регіоні почали збільшуватися і в 2015 р. сягнули 214,4 тис. га (проти 21,9 тис. га у 2005 р.). Виробництво сої збільшилося 332,4 тис. т у 2005 р. до рекордного показника 414,9 тис. т у 2014 p.

Дані, опубліковані на сайті Державної служби статистики України [5] свідчать про те, за підсумками минулого сезону у Київській області зібрали 145,0 тис. т сої. Скорочення посівних площ у 2020 р. до 101,2 тис. га призвело до зменшення виробництва культури загалом по регіону на 50,8 \% порівняно 32019 роком. Цьому посприяло також зниження середньої врожайності з 21,4 т/га у 2019 р. до 1,43 т/га у 2020 році.

Кліматичний режим кожного регіону формується як комплекс особливостей температури, вологості, опадів, вітру, які базуються на закономірностях розподілу радіаційного, теплового та водного балансів i впливу атмосферної циркуляції. Умови температурного режиму i рівня зволоженості Київської області характеризувалися істотними коливаннями температурного режиму і рівня зволоження, особливо за період активної вегетації сої.

Слід зауважити, що за період весняної та літньої вегетації показники середньодобової температури повітря істотно відрізнялися від середньобагаторічних в області, а саме - у квітні місяці із 15 досліджуваних років відмічено 4 випадки, коли ії рівень визначав умови, які істотно відрізнялися від багаторічних значень або були наближені до екстремальних - 4 випадки обумовлені високими, за критерієм істотності відхилень, температурами; травень місяць 2 низькими температурами, 5 - високими.

У червні місяці із 15 досліджуваних років відмічено 6 випадків, коли іiі рівень визначав умови, які істотно відрізнялися від багаторічних значень - 5 випадків обумовлені високими, за критерієм істотності відхилень, температурами, 1 - низькими.

Умови липня та серпня місяців відзначалися наближеними до середньобагаторічних значень у $80 \%$ років досліджень, у $13 \%$ років суттєво відрізнялися від середньобагаторічних значень і були обумовленими високими, за критерієм істотності відхилень температурами, в тому числі i по1 випадку - наближеними до екстремальних умов у липні та серпні місяці, відповідно. Найвищі температури, порівняно із середньобагаторічними значеннями, для липня $\left(19,0^{\circ} \mathrm{C}\right)$ та серпня $\left(18,3^{\circ} \mathrm{C}\right)$ місяців відмічено у $2010 \mathrm{p}$. 
У вересні місяці середньомісячна температура повітря за досліджувані роки (2006-2020рр.) була наближена до середньобагаторічних значень у $73 \%$ років. У $27 \%$ років відмічено іiі суттєве відхилення від середньобагаторічних значень.

Щодо умов зволоження, які визначалися кількістю опадів та рівномірністю їх випадання у часі, то закономірність їх розподілу в умовах регіону за 2006-2020 pр. також мала суттєві відхилення порівняно із середньобагаторічними показниками. Умови весни (квітень - травень) у $27 \%$ років мали суттєве відхилення від середньобагаторічних показників, що викликано надмірним зволоженням. Максимальна кількість опадів за зазначені місяці відмічена у 2006 р. (138 мм), 2008 р. (128 мм), 2014 p. (188 мм), 2016 p. (164 мм), 2019 p. (114 мм) та 2020 р. (152 мм), мінімальна - у 2009 р. (37 мм) та 2018 р. (40 мм) за середньобагаторічних значень - 46,0 та 48,0 мм.

Умови літніх місяців також мали суттєву різницю за надходженням та розподілом опадів і характеризувалися як недостатньою, так i надмірною їх кількістю, що випадали за червень-серпень.

Максимальна кількість опадів червня місяця, які за кількістю були наближені до екстремальних, випала у 2011 р. (126 мм). Однак, протягом 2006-2020 pр. у 2 випадках кількість опадів була істотно нижчою (2015 p - 35 мм та 2017 р. - 24 мм) за середньобагаторічного значення 77 мм.

Умови липня місяця у 1 випадку також характеризувалися як посушливі (2013 р. - 31 мм), і лише 1 рік був обумовлений надмірною кількістю опадів та наближеними до екстремальних (2011 p. - 163 мм).

Найстійкішими за рівнем зволоження у Київському регіоні були серпень та вересень місяць, коли місячна кількість опадів формувала умови, які у $86 \%$ років були наближені до середньобагаторічних значень. Лише у серпні 2012 р. та вересні 2013 р. умови були наближені до екстремальних - випала надмірна кількість опадів - 122 та 160 мм.

У цілому найзволоженішими були 2006 р. (442 мм) та 2011 p. (437 мм); нестача вологи проявлялася у 2009 р. (202 мм), 2015 р. (203 мм) та 2017 р. (225 мм) за середньобагаторічних значень регіону за теплий період 396 мм.

Таким чином, за вегетаційний період сої (квітень-вересень), частка місяців (48 місяці із 90), близьких за кількістю опадів та температурним режимом до середньобагаторічних даних, становить 53,3\%, які суттєво відрізнялися від багаторічних (по 34 місяці) - 37,8\%, з екстремальними умовами (по 8 місяців) - 8,9\%. 
Період спостережень впродовж 15 років є достатнім для забезпечення статистичної значущості коефіцієнта кореляції та його стійкості щодо зрушень часового вікна.

Результати визначення залежності рівня урожайності сої від метеорологічних умов 15 річного періоду (2006-2020 рр.) в Київській області свідчать про те, що визначальними у формуванні врожаю були погодні умови квітня, травня та липня. Рівень тісноти зв'язку комплексу погодних умов 3 урожайністю за величиною коефіцієнта кореляції (R) становив 0,836; 0,606 і 0,485, а частка участі (D) відповідно 69,9; 36,7 і 23,5\%.

На основі проведеного аналізу побудовано прогнозовану модель врожайності. Модель, побудована нами за даними 2006-2020 років, описує взаємозв'язок «врожайність - сума опадів за квітень, середня температура у квітні» $\mathrm{i}$ має такий вигляд: $\mathrm{Y}=-24,3030-$ $1,8389 \mathrm{X}_{1}+13,8813 \mathrm{X}_{1}{ }^{0,5}-0,0362 \mathrm{X}_{2}+0,3425 \mathrm{X}_{2}{ }^{0,5}$, де $\mathrm{Y}-$ урожайність, $\mathrm{X}_{1}$ - температура квітня; $\mathrm{X}_{2}$ - опади квітня;

$\mathrm{R}=0,836$. Фактичне значення $\mathrm{F}$ - критерію Фішера $\mathrm{F}=5,80$; табличне значення $\mathrm{F}-$ критерію Фішера при $\alpha=0,05$ становить $\mathrm{F}=$ 3,48 ; стандартні похибки: $\mathrm{a} 1=0,06 ; \mathrm{a} 2=0,38 ; \mathrm{a} 3=0,003 ; \mathrm{a} 4=0,03$. Оскільки факт $F>$ табличного $F$ можна зробити висновок про адекватність побудованої моделі. Всі параметри моделі є значущими.

Отже, в умовах змін клімату значно зросли посівні площі сої в зонах Лісостепу і Полісся. Проте, як свідчать статистичні дані, рівень іiі врожайності залишається нестабільним за роками. Як свідчить математично-статистичний аналіз, найбільший вплив на рівень врожайності мали погодні умови квітня та травня місяців, коли проводять сівбу культури та проходять початкові стадії розвитку рослин, а також липня місяця, коли відбувається генеративний розвиток. Для зменшення негативного впливу погоди впродовж періоду вегетації культури та створення оптимальних умов, які б відповідали біологічним особливостям культури, необхідністю $\epsilon$ розроблення адаптивних технологій ії вирощування.

\section{Лiтература:}

1. Field C.B., Barros T.F. Stocker D. Qin D.J. Dokken K.L. Ebi M.D. Mastrandrea, K.J., Mach G.-K., Plattner S.K., Allen M., and P.M. Midgley (eds.)]. Cambridge University Press, Cambridge, United Kingdom and New York, NY, USA, 2012. 582 p.

2. Побережный М.С. Влияние глобальных и локальных изменений климата на размещение производства сои в Украине. Масличные 
культуры. Научно-технический бюллетень Всероссийского НИИ масличных культур, 2015. Выл. 2 (162). С. 87-92.

3. Бабич А.О., Бабич-Побережна А.А. Прогнозований вплив глобальних змін клімату на виробництво зернових і зернобобових культур. Засуха, суховій і пилова буря в період глобальних змін клімату. Монографія. Т. 1. Вінниця:ТОВ «Видавництво-друкарня ДІЛО», 2014. С. 399-408.

4. Бабич А.О., Бабич-Побережна А.А. Вплив глобальних і локальних змін клімату на урожайність сільськогосподарських культур в Україні. Засуха, суховій і пилова буря в період глобальних змін клімату. Монографія. Т. 2. Вінниця:ТОВ «Видавництво-друкарня ДІЛО», 2014. C. $162-266$.

5. Державна служба

статистики

України.

URL: http://www.ukrstat.gov.ua/.

DOI https://doi.org/10.30525/978-9934-26-111-4-46

\title{
ВПЛИВ ЗМІНИ КЛІМАТУ В УКРАЇНІ НА СІЛЬСЬКЕ ГОСПОДАРСТВО
}

\author{
Закорчевна Н. Б. \\ кандидат економічних наук, \\ завідувачка кафедри водних екосистем і біоресурсів \\ Державний заклад «Державна екологічна академія післядипломної \\ освіти та управління» \\ Демидюк Ю. С. \\ аспірантка \\ Державний заклад «Державна екологічна академія післядипломної \\ освіти та управління» \\ м. Київ, Украӥна
}

Зміну клімату за останні 30 років називають «антропогенною». Людство впродовж свого існування втручалося в природу і продовжує це робити - вирубує ліси та бездумно розорює землі, порушуючи режим вологості та вітровий режим планети, а також у великих обсягах спалює викопні палива, що $є$ головним джерелом викидів парникових газів. За песимістичними прогнозами, подальше бездумне руйнування 